\title{
The Relationship between Reading Comprehension and Figurative Competence in L2 Learners
}

\author{
Sanaz Doroodi \\ Faculty of Literature and Humanities, Islamic Azad University, Najafabad Branch, Isfahan, Iran \\ Email: s_doroodi@yahoo.com \\ Mahmood Hashemian \\ English Department, Shahrekord University, Shahrekord, Iran \\ Email: m72h@hotmail.com
}

\begin{abstract}
Though many L2 studies have explored the development of figurative language competence (e.g., Cain, Oakhill, \& Lemmon, 2005; Li, 2010), few studies have examined the relationship between idiom comprehension and L2 learners' reading comprehension in consonance with their proficiency levels. This study aimed at assessing the relationship between comprehending opaque and transparent idioms and L2 learners' ability to comprehend a text. It was hypothesized that an $L 2$ learner's proficiency level and figurative competence were interwoven. To do so, 49 Iranian senior B.A. students of English were divided into 2 groups of skilled and less-skilled reading comprehenders in line with the results of a TOEFL test. They were presented with 30 short texts, ending with idiom fragments (e.g., Paul broke the ... for the idiom to break the ice) and asked to select the appropriate words from among the 3 options: idiomatic, literal, and figurative. Later, the same texts were given to 185 freshmen, sophomores, juniors, and seniors to cross-examine their figurative competence. Results revealed that the skilled readers were superior to the less-skilled ones in comprehending both the opaque $(F=25.107, d f=48, \alpha=0.05, p=0.00)$ and the transparent idioms $(F=23.313$, $d f=48, \alpha=0.05, p=0.00)$. Also, from among the 4 university levels, the seniors' performance differed greatly from that of the freshmen, sophomores, and juniors, who did all approximately the same on the idiom test $(F=$ 38.909, $d f=184, \alpha=0.05, p=0.00$ ). Findings may contribute to exploring the process of idiom understanding by demonstrating a link between idiom comprehension and text comprehension. Thus, the growth of one might affect the progress of the other.
\end{abstract}

Index Terms-figurative competence, idiom comprehension, opaque idioms, reading comprehension, transparent idioms

\section{INTRODUCTION}

As stated by Cooper (1999), most English speakers utter about 10 million novel metaphors and 20 million idioms during their lifetime. This is about 3000 novel metaphors and 7000 idioms per week. That is why idioms have long caught the acute eyes of both linguists and psycholinguists (e.g., Gibbs, 1991; Levorato, 1993; Nippold \& Duthie, 2003; Nippold \& Taylor, 2002). As long as idioms are extremely omnipresent in every aspect of L1 speakers' use of language, and as some researchers (e.g., Ellis, 1997; Yorio, 1989) contend, L2 learners need to equip themselves with adequate skills, knowledge, and fitting use and comprehension of idioms. Therefore, idioms are indispensable indicators of L2 learners' fluency that help them integrate into the social communication and cultural aspects of an L2 because idioms are fixed expressions that save effort in processing and act as discoursal time-buyers (Lennon, 1998).

Idiom is highly a heterogeneous community that stretches on a "continuum of compositionality." At one end of the spectrum stand the "transparent idioms," whereas the other end nestles the "opaque idioms." Transparent idioms (e.g., to give somebody the green light) are figurative expressions whose meanings can be effortlessly derivable due to the crystalline connection between the literal meanings of the expressions and their idiomatic interpretations (Boers \& Demecheleer, 2001). On the other hand, the constituent words comprising opaque idioms (e.g., to pull someone's leg) do not make a significance contribution towards the decoding of the idiomatic meaning. Transparent idioms are easier to comprehend which does not bear comparison with the comprehension of opaque idioms. This study adopts a subjective approach towards the classification of transparent and opaque idioms.

Exposure hypothesis is a view that accounts for idiom acquisition. It suggests that the ability to understand the idiomatic meaning is solely achievable via mere exposure and the familiarity of idioms. If so, the comprehension of idioms should not undergo any changes when presented out of context. In addition, exposure hypothesis cannot provide a reliable assumption for the developmental view of idiom comprehension (Cain, Oakhill, \& Lemmon, 2005). By contrast, global elaboration model (GEM) contends that idiom understanding is associated with academic achievements 
in reading (Nippold, Moran, \& Schwards, 2001). That is, the ability to interpret a phrase to the story context is coupled with the ability to comprehend an idiom which can be merely realized through the inclusion of reading texts.

In light of GEM, it is unsubtly predicted that skilled readers are much better able to monitor their understanding of idioms in comparison with less-skilled readers. More specifically, skilled readers make use of various reading skills when they face an idiom, especially an opaque one, such as: (a) the ability to build up inferences moving from the single word level to the sentence level (Oakhill \& Yuill, 1996); (b) the ability to choose the most appropriate meaning of a word from among its several possible meanings (Perfetti, 1999); and (c) the ability to suppress the meanings of the constituent words of an idiom irrelevant to the figurative meaning (Gernsbacher \& Faust, 1991).

However, almost all that has been proposed by GEM has been boundlessly applied to L1 contexts and has not been systematically carried out on L2 learners. This study is regarded to enjoy a sense of novelty because only few previous L2 studies (e.g., Irujo, 1986b; Liontas, 2001, 2002) mainly focused on idiom comprehension by taking the principles of GEM into account. Thus, this study aims at filling this gap by taking the view that L2 learners' idiomatic comprehension might be pertinent to their reading comprehension proficiency.

\section{BACKGROUND TO THE STUDY}

As Gibbs (1980) claims, idioms are the most vital parts of every human language because speakers can express their feelings and experiences better through uttering idioms. That is why the expression to blow your sack is a better representative of one's anger than its literal paraphrase (i.e., to be very angry). A unified definition for idioms has always been a disputable issue. Fernando (1996) defines idioms as "conventionalized multiword expressions often, but not always, nonliteral" (p. 38). Also, Sprenger, Levelt, and Kempen (2006) believe that if there is any relationship between an idiom and its constituent words, it will generally be indirect. Another definition by Saeed (2003) introduces idioms as a group of words that collocate until they are transformed into a fossilized term. Each component word of the collocation is redefined to make an idiomatic expression.

Coming across any figures of speech, specifically idioms in this study, one has to break the walls of literal interpretation and penetrate into the communicative intent of the speakers and dig out their original meaning to let full comprehension take place. However, most idioms can be interpreted both figuratively and literally. What can differentiate between these two correct interpretations is the context in which they are used.

There are two broad views on the representation and processing of idioms called "traditional (noncompositional) views" and "current (compositional) views." According to the traditional views, idioms are regarded as lexical items which exist as chunks and are not recognized by linguistic processing but by memory retrieval. The word noncompositional is implied here to indicate the lack of contribution of idiom constituent in the determination of its meaning. For instance, according to this view, the components of an opaque idiom, such as to kick the bucket have no role in clarifying the idiomatic meaning of this expression. Contrary to the traditional view, the current view believes that idioms are not mainly regarded as noncompositional strings, that is, the relationship between the literal and the idiomatic meaning is not entirely arbitrary. These two general perspectives gave rise to some hypotheses mentioned below.

According to idiom list or literal first hypothesis (Bobrow \& Bell, 1973), idioms are stored in an idiom lexicon as whole chunks which are distinct from the general lexicon. Swinney and Cutler (1979) proposed the lexical representation hypothesis which contrasts with idiom list hypothesis. It emphasizes that idioms are located as a single lexical unit in the general lexicon with other lexical units. Gibbs (1980) puts out the direct access hypothesis (i.e., figurative first hypothesis) to oppose Bobrow and Bell's account. He maintains that after hearing the idiomatic string, the idiomatic meaning will be directly retrieved from the mental lexicon without resorting to the literal sense. Cacciari and Tabossi (1988) criticized the ambiguity of Swinney and Cutler's (1979) lexical representation hypothesis as well as Gibbs' (1980) perspective on idiom interpretation. They based their view on the nonexistence of idioms in the mental lexicon. Moreover, different idioms are processed differently according to this hypothesis. As for the predictable idioms, their idiomatic meaning is motivated when the last component of the idiom string emerges. On the contrary, when unpredictable idioms are heard, their literal meaning is activated first and the idiomatic one is accessed later. On the other hand, the contemporary views of current perspectives focuses on decomposability, that is, if the individual components of an idiom do not contribute to its idiomatic meaning, the idiom is called opaque (e.g., to kick the bucket), but if this contribution takes place, the idiom is termed transparent (e.g., to get away from murder).

Most of what is known about idiom processing and comprehension originates from investigations on children who progressively try to develop their L1 figurative competence (e.g., Arnold \& Hornett, 1990; Levorato \& Cacciari, 1995; Nippold \& Rudzinski, 1993; Titone \& Connine, 1994). However, it is worth appreciating the efforts of those who have tried to offer suggestions on the process of teaching and learning idioms in L2 situations through the conduction of some studies (e.g., Abel, 2003; Duquette, 1995; Irujo, 1986a; Lattey, 1994; Lennon, 1998; Mäntylä, 2004; McCaskey, 1994; Otier, 1986; Richards, 1996; Sadeghi, Vahid Dastjerdi, \& Ketabi 2010). The findings that have been reported to date have not specifically focused on the relationship between idiom comprehension and the ability to comprehend a reading text. Thus, the present study is predominantly an attempt to find out the relationship between comprehending transparent and opaque idioms and reading ability of L2 learners with different levels of reading comprehension by presenting the following questions: 
1. Do the skilled text comprehenders outperform the less-skilled ones in comprehending opaque idioms?

2. Do the skilled text comprehenders outperform the less-skilled ones in comprehending transparent idioms?

3. Does L2 learners' proficiency level make a significant difference in their figurative competence?

It is hoped that the findings of this study may be attributed to L2 pedagogy because, technically speaking, any possible relationship between the ability to comprehend a reading text and idiom understanding may drop some handy hints about what strategies L2 learners need to hinge on to have a better idiomatic understanding.

\section{METHODOLOGY}

\section{A. Participants}

A total number of 185 Iranian freshmen, sophomore, junior, and senior B.A. students of English, including 115 females and 70 males, aged 18-30, were randomly selected from Islamic Azad University of Khorasgan and Shahrekord University. The rationale behind choosing the participants from four levels of university was to study the relationship between their English proficiency and their figurative competence.

\section{B. Materials}

The skilled and the less-skilled readers were selected based on the results of a TOEFL test. The participants were also presented with 30 texts (see Appendix A), including 14 short texts and 16 conversations with one idiom embedded in each and one multiple-choice question following each. The 30 idiomatic expressions, their definitions, and their classification into transparent and opaque idioms are shown in Appendix B.

The criterion for counting an expression as an idiom was NTC's American Idioms Dictionary (2000). The texts were extracted from three sources: Live Idioms in the Context (2004), English Idioms in Use (2002), and 101 American English Idioms (1994). As for the selection of the conversations, the books Speak English Like an American (2004), Basic Idioms in American English (1981), and 101 American English Idioms (1994) were consulted. Each text was followed by one multiple-choice question designed by five English native speakers. Some options of the multiplechoice questions were also driven from among the examples given for the entries in Oxford Advanced Learner's Dictionary (2002).

\section{Procedure}

Prior to the experimental phase, a list of 35 idioms was given to 20 English teachers and two English university professors, and they were requested to divide the idioms into two groups of 15 opaque and 15 transparent idioms. After the classification of the idioms was made, one multiple-choice question was designed for each reading text, including three choices: idiomatic, figurative, and literal choices, among which the idiomatic choice was the correct answer. The figurative choices (e.g., to break the morale) were provided by five native speakers of English settling in London because they were neither idiomatic expressions nor literal ones and could not be profoundly found in reliable sources. After piloting $(r=0.78)$ the texts via Cronbach's Alpha, a group of 185 participants, including 32 freshmen, 54 sophomores, 50 juniors, and 49 seniors were presented with 30 texts to have their figurative competence crossexamined.

In addition, for the sake of determining the relationship between idiom comprehension and reading proficiency of the participants, the same 49 seniors were presented with a paper-based TOEFL test. After the results were revealed, the participants were divided into 25 less-skilled and 24 skilled readers who were presented with the reading texts.

\section{DATA ANALYSIS}

As seen in Tables 1 and 2, both the skilled and the less-skilled reading comprehenders showed a significant difference in comprehending the transparent idioms $(F=23.313, d f=1, \alpha=0.05, p=0.000)$ and the opaque ones $(F=$ 25.107, $d f=1, \alpha=0.05, p=0.000)$.

TABLE 1.

ONE -WAY ANNOVA FOR THE COMPREHENSION OF THE TRANSPARENT IDIOMS

\begin{tabular}{|l||l|l|l|l|l|}
\hline \multicolumn{1}{|l|}{ Source } & $\begin{array}{l}\text { Type III Sum of } \\
\text { Squares }\end{array}$ & $d f$ & $\begin{array}{l}\text { Mean } \\
\text { Square }\end{array}$ & $\boldsymbol{F}$ & Sig. \\
\hline \hline Corrected Model & $140.082^{\mathrm{a}}$ & 1 & 140.082 & 23.313 & .000 \\
\hline Intercept & 5908.572 & 1 & 5908.572 & 983.339 & .000 \\
\hline Level & 140.082 & 1 & 140.082 & 23.313 & .000 \\
\hline Error & 282.408 & 47 & 6.009 & & \\
\hline Total & 6242.000 & 49 & & & \\
\hline Corrected Total & 422.490 & 48 & & \\
\hline
\end{tabular}


TABLE 2.

ONE -WAY ANNOVA FOR THE COMPREHENSION OF THE TRANSPARENT IDIOMS

\begin{tabular}{|l||c|c|c|c|c|}
\hline Source & $\begin{array}{c}\text { Type III Sum of } \\
\text { Squares }\end{array}$ & $\boldsymbol{d} f$ & $\begin{array}{c}\text { Mean } \\
\text { Square }\end{array}$ & $\boldsymbol{F}$ & Sig. \\
\hline \hline Corrected Model & $99.326^{\mathrm{a}}$ & 1 & 99.326 & 25.107 & .000 \\
\hline Intercept & 4847.407 & 1 & 4847.407 & 1225.279 & .000 \\
\hline level & 99.326 & 1 & 99.326 & 25.107 & .000 \\
\hline Error & 185.940 & 47 & 3.956 & & \\
\hline Total & 5066.000 & 49 & & & \\
\hline Corrected Total & 285.265 & 48 & & & \\
\hline
\end{tabular}

As $p$ value is less than $\alpha$, the first and the second null hypotheses presented below are rejected:

- There is no difference between the skilled text comprehenders and the less-skilled ones in comprehending the transparent idioms.

- There is no difference between the skilled text comprehenders and the less-skilled ones in comprehending the opaque idioms.

In order to measure the potential difference between the mean scores of the four groups, the scores of the idiom test were subjected to statistical analysis, applying a one-way ANOVA (see Table 3):

TABLE 3.

ONE-WAY ANNOVA FOR THE FOUR GROUPS

\begin{tabular}{|l||c|c|c|c|c|}
\hline \multirow{2}{*}{ Source } & $\begin{array}{c}\text { Type III Sum } \\
\text { of Squares }\end{array}$ & $\boldsymbol{d} \boldsymbol{f}$ & $\begin{array}{c}\text { Mean } \\
\text { Square }\end{array}$ & $\boldsymbol{F}$ & Sig. \\
\hline \hline Corrected Model & $2695.836^{\mathrm{a}}$ & 3 & 898.612 & 38.909 & .000 \\
\hline Intercept & 35805.785 & 1 & 35805.785 & 1550.373 & .000 \\
\hline level & 2695.836 & 3 & 898.612 & 38.909 & .000 \\
\hline Error & 4180.186 & 181 & 23.095 & & \\
\hline Total & 45584.000 & 185 & & & \\
\hline Corrected Total & 6876.022 & 184 & & & \\
\hline
\end{tabular}

As Table 3 shows, the four groups differed from one another regarding their figurative competence $(\mathrm{F}=38.909$, $\mathrm{df}=$ $3, \alpha=0.05, \mathrm{p}=0.000)$. As $\mathrm{p}$ value is less than $\alpha$, the third null hypothesis presented below is rejected, too:

- L2 learners' proficiency level does not make a significant difference in their figurative competence.

In order to find the pair groups that were significantly different, the scores of the four groups were subjected to posthoc analysis shown in Table 4:

TABLE 4.

MULTIPLE COMPARISONS OF THE FOUR GROUPS

\begin{tabular}{|c|c|c|c|c|c|c|c|}
\hline \multirow{14}{*}{$\begin{array}{l}0 \\
0 \\
5\end{array}$} & \multirow{2}{*}{$\begin{array}{l}\text { (I) } \\
\text { Proficiency } \\
\text { Level }\end{array}$} & \multirow{2}{*}{$\begin{array}{c}(\mathbf{J}) \\
\text { Proficiency } \\
\text { Level }\end{array}$} & \multirow{2}{*}{$\begin{array}{c}\text { Mean } \\
\text { Difference } \\
\text { (I-J) }\end{array}$} & \multirow[b]{2}{*}{$\begin{array}{l}\text { Std. } \\
\text { Error }\end{array}$} & \multirow[b]{2}{*}{ Sig. } & \multicolumn{2}{|c|}{$\begin{array}{c}\text { 95\% Confidence } \\
\text { Interval }\end{array}$} \\
\hline & & & & & & $\begin{array}{l}\text { Lower } \\
\text { Bound }\end{array}$ & $\begin{array}{l}\text { Upper } \\
\text { Bound }\end{array}$ \\
\hline & \multirow[t]{3}{*}{ Freshmen } & Sophomores & -1.63 & 1.072 & .131 & -3.74 & .49 \\
\hline & & Juniors & -2.14 & 1.088 & .051 & -4.29 & .01 \\
\hline & & Seniors & $-9.93^{*}$ & 1.092 & .000 & -12.09 & -7.78 \\
\hline & \multirow[t]{3}{*}{ Sophomores } & Freshmen & 1.63 & 1.072 & .131 & -.49 & 3.74 \\
\hline & & Juniors & -.51 & .943 & .587 & -2.37 & 1.35 \\
\hline & & Seniors & $-8.31^{*}$ & .948 & .000 & -10.18 & -6.44 \\
\hline & \multirow[t]{3}{*}{ Juniors } & Freshmen & 2.14 & 1.088 & .051 & -.01 & 4.29 \\
\hline & & Sophomores & .51 & .943 & .587 & -1.35 & 2.37 \\
\hline & & Seniors & $-7.79^{*}$ & .966 & .000 & -9.70 & -5.89 \\
\hline & \multirow[t]{3}{*}{ Seniors } & Freshmen & $9.93^{*}$ & 1.092 & .000 & 7.78 & 12.09 \\
\hline & & Sophomores & $8.31^{*}$ & .948 & .000 & 6.44 & 10.18 \\
\hline & & Juniors & $7.79^{*}$ & .966 & .000 & 5.89 & 9.70 \\
\hline
\end{tabular}

Table 4 shows that the major difference was between the seniors' figurative competence and the other three groups (i.e., freshmen, sophomores, and juniors) because $p$ value is less than $\alpha(\alpha=0.05, p=.000)$.

\section{DISCUSSION AND CONCLUSION}

This research was primarily undertaken to seek for the possible relationship between the ability to comprehend a reading text and the ability to understand opaque and transparent idioms in relation to four proficiency levels (i.e., freshmen, sophomores, juniors, and seniors) of Persian L2 learners. The findings indicated that the seniors, considered to have the highest proficiency level, outperformed the other three levels in comprehending both the transparent and the 
opaque idioms. However, regarding idiom comprehension, and surprisingly enough, the freshmen, sophomores, and juniors did not exhibit significant statistical differences. Hence, it is within a compelling reason to conclude that L2 learners' proficiency level and idiom comprehension are positively associated. That is, the more L2 learners improve their proficiency level, the better they are able to infer that a literal interpretation of an idiom is inconsistence with the surrounding semantic context of the idiom.

The other questions of this study were posed to see if the senior skilled and the less-skilled readers perform differently in comprehending the opaque and the transparent idioms. The results indicated that the skilled readers overrode the less-skill ones in comprehending both types of idioms, which is in line with those of GEM. As mentioned earlier, GEM, which was suggested by Levorato and Cacciari (1995, 1999), predicts that inadequate reading comprehension skills deteriorate the ability to follow the coherence of the reading text in order to put the required information together which can be used for the deduction of the nonliteral interpretation of idioms. GEM was mostly applied in L1 contexts, but the results of this study can confirm its reliable application for L2 learners because it supports the fact that the ability to chose the idiomatic answers is based on the capacity to construct a coherent semantic representation of the story context. Accordingly, Cain, Oakhill, and Lemmon (2005) maintain that "context might facilitate the interpretation of figurative language by providing the necessary semantic information from which readers can extract or infer the appropriate sense of expression" (p. 67).

To encapsulate, if L2 instructors and researchers hope to make a substantial contribution into the domain of figurative competence, they are requested to abandon to treat idioms as other lexical items which can be learnt by L2 learners on their own. This Cinderella's sister (i.e., idiom) deserves to be positioned more desirably in L2 curricula by its inclusion in natural contexts similar to those of L1. Also, future research could address other variables rather than context and idiom type to widen further views on the way idioms are comprehended.

\section{APPENDIX A SAMPLE TEXT \& CONVERSATION WITH AN EMBEDDED IDIOM FRAGMENT}

Directions: Please read the following text. Choose the best choice and mark it $(\sqrt{ })$ on your answer-sheet.

Peter decided to clean the house to surprise his mother. When he was dusting, he suddenly knocked over an expensive pot which was very special for his mom. He was so panicked and sad. When his mother got home, he wanted to tell her everything. It was very difficult to break the
1. a) pot
b) ice
c) morale

Liz: Did you know that Harry was going to take Kathy on south waters?

Tom: Yeah! He was planning on surprising her with the tickets for their anniversary, but someone spilled the .......... .

Liz: What a shame! That was supposed to be a surprise.
2. a) waters
b) emotions
c) beans

APPENDIX B TYPES OF IDIOMS, IDIOMS, \& DEFINITIONS 


\begin{tabular}{|c|c|c|}
\hline Type of Idioms & Idioms & Definitions \\
\hline \multirow{15}{*}{ Transparent } & To bury the hatchet & To stop fighting or arguing \\
\hline & To stick to one's guns & To remain firm in one's convictions \\
\hline & To shed (some) light on something & To reveal something about something \\
\hline & To break the ice & To get something started \\
\hline & To leave somebody out in the cold & To exclude someone \\
\hline & To keep one's fingers crossed & To wish for luck for someone or something \\
\hline & To step into one's shoes & To take over a job or some role from someone \\
\hline & To lose one's temper & To become angry \\
\hline & To burn one's bridges & To make decisions that cannot be changed in the future \\
\hline & To cost an arm and a leg & To cost too much \\
\hline & To keep one's chin up & To keep one's spirit high \\
\hline & To twist somebody's arm & To force or persuade someone \\
\hline & To give someone the cold shoulder & To ignore someone \\
\hline & To leave somebody high and dry & To leave someone helpless \\
\hline & To roll up one's sleeves & To get ready to do some work \\
\hline \multirow{15}{*}{ Opaque } & To give something a shot & To try something \\
\hline & To kick the bucket & To die \\
\hline & To give someone the slip & To escape from or elude someone \\
\hline & To bite the bullet & To put up with or endure something \\
\hline & To spill the beans & To reveal a secret or a surprise by accident \\
\hline & To hit the books & To begin to study \\
\hline & To bite the dust & To fall to defeat \\
\hline & To make a bundle & To make a lot of money \\
\hline & To get off one's case & To stop picking on someone \\
\hline & To pull somebody’s leg & To kid, fool, or trick someone \\
\hline & To blow one's top & To become very angry \\
\hline & To hit the roof & To become very angry \\
\hline & To lose one's shirt & To lose all of one's assets \\
\hline & To hold one's horses & To wait a minute and be reasonable \\
\hline & To beat around the bush & To waste time \\
\hline
\end{tabular}

\section{REFERENCES}

[1] Abel, B. (2003). English idioms in the first language and second language lexicon: A dual representation approach. Journal of Second Language Research 19, 329-358.

[2] Arnold, K. M. \& Hornett, D. (1990). Teaching idioms to children who are deaf. Journal of Teaching Exceptional Children 22.4, 14-17.

[3] Boers, F. \& Demecheleer, M. (2001). Measuring the impacts of cross-cultural differences on learners' comprehension of imageable idioms. ELT Journal 55.3, 255-262.

[4] Bobrow, S. A. \& Bell, S. M. (1973). On catching on to idiomatic expressions. Journal of Memory \& Cognition 1.3, 343-346.

[5] Cacciari, C. \& Tabossi, P. (1988). The comprehension of idioms. Journal of Memory and Language 27.6, 668-683.

[6] Cain, K., Oakhill, J. \& Lemmon, K. (2005). The relation between children's reading comprehension level and their comprehension of idioms. Journal of Experimental Child Psychology 90, 65-87.

[7] Cooper, T. C. (1999). Processing of idioms by L2 learners of English. Journal of TESOL Quarterly 33.2, 233-262.

[8] Collis, H. (1994). 101 American English idioms. Chicago: NTC Publishing Group.

[9] Duquette, G. (1995). Developing comprehension and interaction skills with idiomatic expressions. In G. Duquette (Ed.), Second language practice: Classroom strategies for developing communicative competence. Clevedon, England: Multilingual Matters, 35-42.

[10] Ellis, N. (1997). Vocabulary acquisition: Word structure, collocation, word-class, and meaning. In N. Schmitt \& M. McMarthy (Eds.), Vocabulary, description, acquisition and pedagogy. Cambridge: CUP, 122-139.

[11] Fernando, C. (1996). Idioms and Idiomaticity. Oxford University Press.

[12] Gernsbacher, M. A. \& Faust, M. (1991). The mechanism of suppression: A component of general comprehension skill. Journal of Experimental Psychology: Learning, Memory and Cognition 17, 245-262.

[13] Gibbs, R. W. Jr. (1980). Spilling the beans on understanding and memory for idioms in conversation. Journal of Memory \& Cognition 8.2, 149-156.

[14] Gibbs, R. W. Jr. (1991). Semantic analyzability in children's understanding of idioms. Journal of Speech and Hearing Research 34, 613-620.

[15] Gillett, A. (2004). Speak English like an American. Michigan: Language Success Press.

[16] Hornby, S. A. \& Wehemeier, S. (2002). Oxford advanced learner's dictionary (6th ed.). Oxford University Press.

[17] Hubert, H. \& Setzler, J. R. (1981). Basic idioms in American English. Chicago: Science Research Association, Inc.

[18] Irujo, S. (1986a). Don't put your leg in your mouth: Transfer in the acquisition of idioms in a second language. Journal of TESOL Quarterly 20.2, 287-304.

[19] Irujo, S. (1986b). A piece of cake: Learning and teaching idioms. ELT Journal 40.3, 236-242.

[20] Lattey, E. (1994). Inference and learnability in second language acquisition: Universals vs. language-specific phenomena in the domain of idiomatic expression. In R. Tracy \& E. Lattey (Eds.), How tolerant is universal grammar? Tübingen: Niemeyer, 295-312. 
[21] Lennon, P. (1998). Approaches to the teaching of idiomatic language. Journal of International Review of Applied Linguistics in Language Teaching 36, 11-30.

[22] Levorato, M. C. (1993). The acquisition of idioms and the development of figurative competence. In C. Cacciari \& P. Tabossi (Eds.), Idioms: Processing, structure, and interpretation. Hillsdale, NJ: Lawrence Erlbaum Associates, 101-128.

[23] Levorato, M. C. \& Cacciari, C. (1995). The effects of different tasks on the comprehension and production of idioms in children. Journal of Experimental Child Psychology 60, 261-283.

[24] Levorato, M. C. \& Cacciari, C. (1999). Idiom comprehension in children: Are the effects of semantic analyzability and context separable? European Journal of Cognitive Psychology 11.1, 51-66.

[25] Li, X. (2010). A comparative analysis of English and Chinese idioms-From the perspective of conceptual metaphor of "Happiness." Journal of Language Teaching and Research 1.4, 473-476.

[26] Liontas, J. I. (2001). That's all Greek to me! The comprehension and interpretation of Modern Greek phrasal idioms. Journal of the Reading Matrix 1.1, 1-31.

[27] Liontas, J. I. (2002). Reading between the lines: detecting, decoding, and understanding idioms in second languages. In J. H. Sullivan (Ed.), Literacy and the second language learner. Greenwich, Connecticut: Information Age Publishing Inc, 177-216.

[28] Mäntylä, K. (2004). Idioms and language users: The effect of the characteristics of idioms on their recognition and interpretation by native and non-native speakers of English. Retrieved September 27, 2010, from the World Wide Web: http://selene.lib.jyu.fi:8080/vaitos/studies/studhum/9513917177.pdf

[29] McCarthy, M. \& O’Dell, F. (2002). English idioms in use. Cambridge University Press.

[30] McCaskey, M. (1994). Teaching Japanese idioms using hypercard: An idiom module for a learner's dictionary. Journal of Computer Assisted Language Learning 7, 99-106.

[31] Nippold, M. A. \& Duthie, J. K. (2003). Mental imagery and idiom comprehension: A comparison of school-age children and adults. Journal of Speech, Language, and Hearing Research 46, 788-799.

[32] Nippold, M. A., Moran, C. \& Schwards, I. E. (2001). Idiom understanding in preadolescents: Synergy in action. American Journal of Speech and Language Pathology 10, 169-179.

[33] Nippold, M. A. \& Rudzinski, M. (1993). Familiarity and transparency in idiom explanation: A developmental study of children and adolescents. Journal of Speech and Hearing Research 36.2, 728-737.

[34] Nippold, M. A. \& Taylor, C. L. (2002). Judgments of idiom familiarity and transparency: A comparison of children and adolescents. Journal of Speech, Language, and Hearing Research 45, 384-391.

[35] Oakhill, J. \& Yuill, N. (1996). Higher order factors in comprehension disability: Processes and remediation. In C. Cornoldi \& J. Oakhill (Eds.), Reading comprehension difficulties: Processes and intervention. Mahwah, NJ: Erlbaum, 69-92.

[36] Otier, M. H. (1986). Teaching idiomatic expressions: Letting the cat out of the bag. Journal of Zielsprache Englisch 16, $31-33$.

[37] Perfetti, C. A. (1999). Comprehending written language: A blueprint of the comprehender. In C. M. Brown \& P. Hagoort (Eds.) The neurocognition of language. Oxford University Press, 167-208.

[38] Richards, J. C. (1996). Reflections on language teaching: Idiomatically speaking. Journal of Zielsprache Englishch 26.3, $32-33$.

[39] Rostamzadeh, A., Khodayari, H. R. \& Noroozian, B. (2004). Live idioms in the context. Iran, Tehran: Moalefan.

[40] Sadeghi. B., Vahid Dastjerdi, H. \& Ketabi, S. (2010). Patterns of Persian EFL learners' comprehension of idiomatic expressions: Reading strategies and cross-cultural mappings in focus. Journal of Asian Social Science 6.8, 81-99.

[41] Saeed, J. I. (2003). Semantics. Oxford: Blackwell.

[42] Spears, R. A. (2000). NTC's American idioms dictionary. Chicago: NTC's Publishing Group.

[43] Sprenger, S. A., Levelt, W. J. M. \& Kempen, G. (2006). Lexical access during the production of idiomatic phrases. Journal of Memory and Language 54, 161-184.

[44] Swinney, D. A. \& Cutler, A. (1979). The access and processing of idiomatic expressions. Journal of Verbal Learning \& Verbal Behavior 18, 523-534.

[45] Titone, D.A. \& Connine, C. M. (1994). The comprehension of idiomatic expressions: Effects of predictability and literality. Journal of Experimental Psychology: Learning, Memory and Cognition 20, 1126-1138.

[46] Yorio, C. (1989). Idiomaticity as an indicator of second language proficiency. In K. Hyllenstam \& L. K. Olber (Eds.), Bilingualism across the lifespan. Cambridge: CUP, 55-72.

Sanaz Doroodi is an M.A. TEFL graduate of Islamic Azad University, Najafabad Branch. She is currently teaching English at Isfahan language schools at various levels. And, her areas of interest include discourse analysis, sociolinguistics, and L2 methodology.

Mahmood Hashemian is an assistant professor at Shahrekord University. His area of research includes cognitive-semantic linguistics, sociolinguistics, and applied linguistics. He has published articles in academic journals such as IJAL, IJLS, JALS, Linguistik-Online, JLTR, TPLS, Iranian EFL Journal, and International Journal of Social Sciences. Also, he has given lectures in conferences such as TELLSI (4, 7, \& 8), LDP2010, ELT in the Islamic World, and 2nd International Language Conference (ILC) 2011, Malaysia. 